\title{
GEOGRAFIA E DISCURSOS ACERCA DE IDENTIDADES E DIFERENÇAS NO ESPAÇO ESCOLAR EM REDENÇÃO, PARÁ
}

\section{GEOGRAPHY AND DISCOURSES ABOUT IDENTITIES AND DIFFERENCES IN, PARÁ \\ GEOGRAFÍA Y DISCURSOS ACERCA DE IDENTIDADES Y DIFERENCIAS EN EL ESPACIO ESCOLAR EN REDENCIÓN, PARÁ}

\author{
José Rodrigues de Carvalho ${ }^{1}$ \\ Vanilton Camilo de Souza² \\ Alex Ratts ${ }^{3}$
}

\begin{abstract}
RESUMO
A partir de entrevistas com docentes, o presente artigo procura analisar discursos de professoras e professores de Geografia acerca das identidades e diferenças étnicas e regionais no espaço escolar. 0 texto é parte da pesquisa em andamento em nível de doutorado. Nele, trata-se de compreender como as identidades e as diferenças são discursivamente construídas no espaço escolar e que mecanismos estão implicados em suas construções, determinando a valorização de algumas em detrimento de outras. Considera-se o espaço escolar como o lugar de relações, sentido do pertencimento e de constituição de identidades dos sujeitos escolares e de experiências com a alteridade cultural. Adota-se a entrevista semiestruturada como procedimento qualitativo para a elaboração do material primário. Percebe-se até o momento que os enunciados das/os docentes são atravessados pela identificação das diferenças étnicas e regionais que emergem no cotidiano da escola, mas que encontram pouco espaço de reflexão e debate. Sendo assim, considera-se relevante que o ensino de Geografia para futuras/os professoras e professores priorize abordagens que percebam e valorizem a pluralidade que institui o espaço escolar.
\end{abstract}

Palavras-chave: Alteridade. Cultural. Discurso docente. Etnia. Justiça social. Regional.

\begin{abstract}
From interviews with teachers, this article seeks to analyze discourses of teachers and teachers of Geography about the identities and ethnic and regional differences in the school space. The text is part of in progress research the doctoral level. It attempts to comprehend how identity and differences are discursively built at school space and which mechanisms are implied in its constructions, as to determine the valorization of some in detriment of others. School space is considered as the place of relations, meaning of belonging and identity building of school subjects and cultural alterity experiences. Semi-structured interviews were adopted as qualitative proceedings to elaborate main data. It is noticed that teachers enunciates are intercepted by ethnic and regional differences that emerge on school daily life, which, however, find little space of reflection and debate. Thus, it is considered relevant that Geography teaching for future teachers prioritize approaches that notice and enriches school space plurality.
\end{abstract}

Keywords: Alterity. Culture. Teacher discourse. Social justice. Ethnic. Regional.

\section{RESUMEN}

A partir de entrevistas con docentes, el presente artículo busca analizar discursos de profesoras y profesores de Geografía acerca de las identidades y diferencias étnicas y regionales en el espacio escolar. El texto es parte de la investigación en curso a nivel de doctorado. En él se trata de comprender cómo las identidades y las diferencias regionales son discursivamente construidas en el espacio escolar y qué mecanismos están implicados en sus construcciones, lo cual determina la valorización de algunas identidades y diferencias, en detrimento de otras. Se considera el espacio escolar como el lugar de relaciones, sentido de la pertenencia y de constitución de identidades de los sujetos escolares y de experiencias con la alteridad cultural. Utilizamos la entrevista semiestructurada como procedimiento cualitativo para la elaboración del material

\footnotetext{
Universidade Federal de Goiás (UFG). Redenção - PA, Brasil. ORCID: http://orcid.org/0000-0003-2938-3159. E-mail: zecaupoeta@hotmail.com.

2 Universidade Federal de Goiás (UFG). Goiânia - GO, Brasil. ORCID: http://orcid.org/0000-0003-4959-0673. E-mail: souzacamilo@gmail.com.

3 Universidade Federal de Goiás (UFG). Goiânia - GO, Brasil. ORCID: http://orcid.org/0000-0003-1656-847X. E-mail: alex.ratts@uol.com.br.
}

Artigo recebido em outubro de 2018. Aprovado em agosto de 2019.

Cad. Pesq., v. 26, n. 3, jul./set., 2019. 
primario. Hasta el momento, se percibe que los enunciados de las / los docentes son atravesados por la identificación de las diferencias étnicas y regionales que emergen en el cotidiano de la escuela, pero que encuentran poco espacio de reflexión y debate. De esta forma, consideramos relevante que la enseñanza de Geografía para futuras/ os profesoras y profesores priorice enfoques que perciban y valoren la pluralidad que instituye el espacio escolar.

Palabras clave: Alteridad. Cultural. Discurso docente. Etnia. Justicia social. Regional.

\section{INTRODUÇÃO}

O espaço escolar, objeto de importantes discussões, é constituído pela pluralidade de identidades e diferenças étnicas e regionais que se formam por meio de discursos e relações que nele ocorrem. No entanto, os estudos da Geografia escolar têm dado pouca atenção a esse fenômeno geográfico, no sentido de pouco procurar compreender como o mesmo é discursivamente representado e vivenciado pelo corpo docente de Geografia. Sendo assim, a pesquisa buscou, através de diálogos com onze docentes dessa disciplina, perceber a constituição discursiva do espaço escolar em unidades públicas de Ensino Fundamental, Anos Finais, pensando o espaço a partir da perspectiva relacional de Doreen Massey.

Tomemos aqui o espaço escolar como lugar de ensino e aprendizagem geográficos, relações, sentido de pertencimento e de constituição de identidades biográficas dos sujeitos escolares e de experiências com a alteridade cultural. Procurando cobrir essas dimensões espaciais, a pesquisa alcança a área de sete escolas públicas municipais da zona urbana de Redenção, município localizado na Amazônia Oriental que, segundo Lima (2013), foi fundado na década de 60 e está situado na Bacia do Rio Paudarquinho, no cruzamento das rodovias PA-287 e BR-158, no Sul do Estado do Pará.

Buscar compreender questões pertinentes ao espaço da escola, à educação e às relações entre seus sujeitos, tem motivações que perpassam nossa trajetória de experiência docente, ensinando Geografia na educação básica e superior em uma região tida como "fronteira migratória:" a Amazônia Oriental. A trama do encontro entre os "sujeitos migrantes" na escola nos instigou a empreender um olhar mais denso para a Geografia, o ensino e a alteridade, a partir de discursos docentes acerca de diferenças e identidades étnicas e regionais no espaço escolar.

Para discutir a questão, campos teórico-metodológicos como os Estudos Culturais, a Geografia cultural e a Análise do Discurso, se somaram à Geografia escolar. A pesquisa se situa em uma justaposição da Geografia escolar com essas outras abordagens. Em nossa condição de sujeito cultural e também na condição de migrante, que experiência questões de alteridade no espaço escolar cotidianamente, muito nos importa compreender as inscrições das identidades culturais dos sujeitos nas diferentes formações discursivas, considerando que "os discursos exprimem uma memória coletiva na qual os sujeitos e suas identidades estão inscritos" (FERNANDES, 2008 , p. 42) e demonstram também nuances das relações de poder.

O interesse pelo desvelamento de como as identidades e as diferenças étnicas e regionais são significadas na escola, através dos discursos docentes, converge para a concepção que temos do espaço escolar: um lugar de relações com regras de "apresentação dos corpos e construção de identidades hegemônicas e subalternas" (COSTA, 2016, p. 204), mas que, apesar do seu viés de espaço onde se "verifica a hierarquização das expressões de identidade", carrega também um potencial para representações e relações que promovam o reconhecimento e a expressão das alteridades e a justiça social.

Entendido o espaço escolar como lugar de vivência dos sujeitos escolares, objetivamos identificar e analisar como as(os) professoras(es) de Geografia percebem e trabalham a pluralidade, particularmente a regional e étnica, em suas práticas docentes cotidianas, bem como os desafios que encontram na lida com essas temáticas na escola. Trata-se, portanto, de compreender como as identidades e as diferenças 
são construídas no espaço escolar e que mecanismos estão implicados em suas construções, determinando a valorização de umas e o desprestígio de outras. É nesse contexto que emerge a defesa do olhar da Geografia para a pluralidade cultural no espaço da educação.

Conforme as Diretrizes Curriculares Nacionais da Educação Básica de 2013, nas últimas décadas, o direito à diferença tem se firmado como resultado de movimentos sociais, assim como o Direito de grupos específicos tem atendidas suas demandas, não apenas de natureza social, mas também individual. Ele tem como fundamento a ideia de que devem ser consideradas e respeitadas as diferenças que fazem parte do tecido social, bem como deve ser assegurado lugar a sua expressão, pois, o direito à diferença, assegurado no espaço público, significa não apenas a tolerância ao outro, aquele que é diferente de nós, mas implica a revisão do conjunto dos padrões sociais de relações da sociedade, exigindo uma mudança que afeta a todos, o que significa que a questão da identidade e da diferença tem caráter político. O direito à diferença se manifesta por meio da afirmação dos direitos das crianças, das mulheres, dos jovens, dos homossexuais, dos negros, dos indígenas, das pessoas com deficiência, entre outros, que para de fato se efetivarem, necessitam ser socialmente reconhecidos (BRASIL, 2013, p. 105).

$\mathrm{O}$ direito à diferença, garantido nas Diretrizes, busca resguardar que, em nome da igualdade não se desconsiderem as diferenças culturais, de cor/raça/etnia, gênero, idade, sexualidade, entre outras. Em decorrência, espera-se que a escola esteja atenta a essas diferenças, a fim de que em torno delas não se construam mecanismos de exclusão que impossibilitem a concretização do direito à educação, que é um direito de todos e um caminho para a promoção da justiça social no espaço escolar e na sociedade em geral.

No estudo estamos em busca de sentidos de discursos (ORLANDI, 2015), sobre identidades e diferenças étnicas e regionais, presentes nas falas das professoras e professores em entrevista e em práticas didáticas na sala de aula. Nos discursos orais procuramos sentidos advindos das experiências relacionais no Ensino de Geografia e também das memórias discursivas sobre diferenças regionais e étnicas que atravessam os sujeitos envolvidos na pesquisa, pois se sabe que a escola, como espaço de possibilidades para a produção de silenciamentos baseados na simplificação ou naturalização de certos discursos e práticas excludentes, é também um espaço propício para o questionamento de tal naturalização.

No caso específico das escolas lócus da pesquisa - em Redenção, Pará - estamos considerando-as como "espaço de fronteira, que é marcado pela desigualdade, segregação sócio-cultural e conflitos" (PINEDA-ALFONSO, 2016, p. 32). Nesse espaço o Ensino de Geografia pode ser uma tecnologia social de intervenção para a construção de convivência em equidade com a alteridade do outro, e o estabelecimento de relações mais reconhecedoras e valorizadoras da pluralidade das identidades e diferenças presentes no espaço escolar.

O município de Redenção pertence a um "grupo de cidades formadas sob o impacto das migrações recentes e constituíram-se em corredor migratório para outras regiões do Estado e de toda a Amazônia" (SILVA, I., 2006, p. 44). Essas migrações se deram e, ainda se dão - agora em menor proporção - por uma população social e culturalmente heterogênea, de diferentes estados e regiões do país, onde é possívelperceber que há maior incidência de migrantes nordestinos e nortistas (principalmente dos estados do Maranhão e Tocantins) e, em menor quantidade, dos estados do Centro-Sul. 


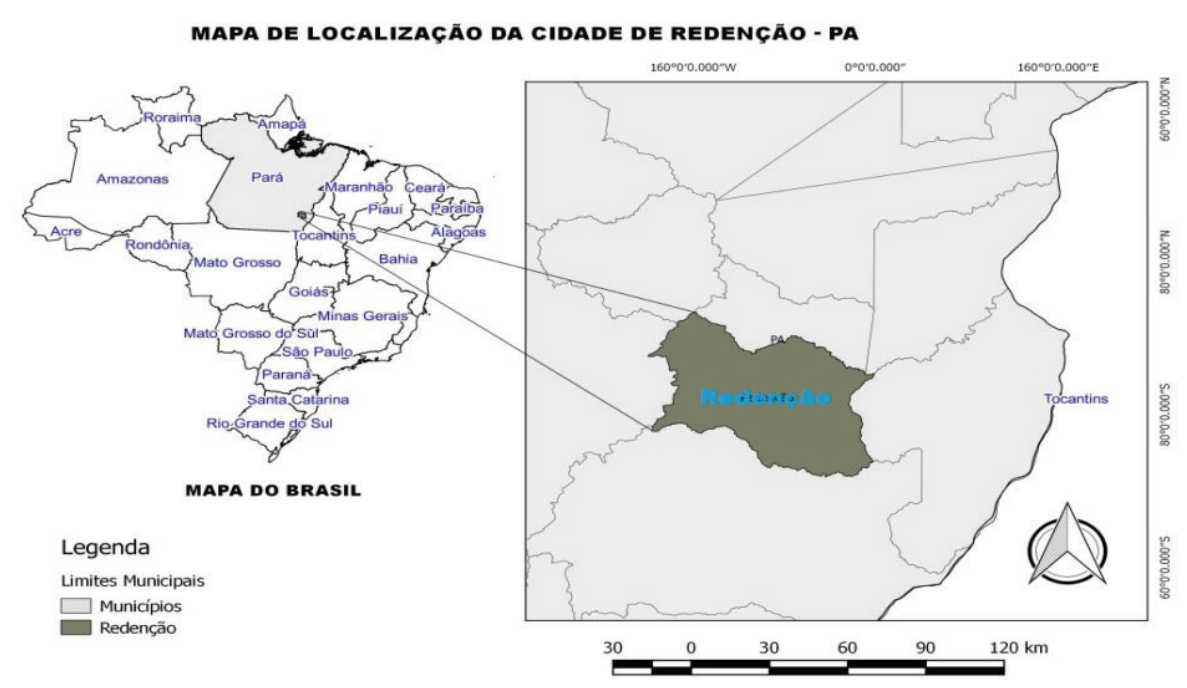

Fonte: www.google.com.br. Org.: Reis, R. H. S., 2018.

As levas de migrantes para o Sul do Pará encontraram e encontram ali, milhares de indígenas do povo Mebêngôkre-Kayapó ${ }^{4}$, pois, dos 39 grupos indígenas territorializados no estado do Pará, parte deles está no Sul do estado, mais precisamente em Redenção e municípios adjacentes. Muitas famílias indígenas residem na zona urbana e seus filhos estudam juntamente com os filhos dos migrantes não indígenas nas escolas públicas municipais. É importante ressaltar que não há professoras(es) indígenas nas escolas de Redenção, mesmo assim, consideramos que as diferenças culturais regionais e étnicas fazem parte do espaço dessas escolas, dando lhe um caráter pluricultural e pluriétnico no tocante à constituição do corpo docente.

Idelma Santiago da Silva I. (2006, p. 153), que estudou "migração e cultura no Sudeste do Pará" identificou que a maioria dos migrantes para a citada área amazônica é originária de grupos subalternos, como aqueles que migraram do baixo Tocantins, dos estados de Goiás e Tocantins e do Nordeste brasileiro. Conforme essa autora, "nos novos espaços ocupados, as relações entre estes e/ou outros grupos de migrantes foram de solidariedade, mas também de alteridade e construção de estereótipos discriminatórios".

As múltiplas identidades culturais que ali se relacionam, apresentam certa "plasticidade cultural", no entanto, por outro lado, essas relações se apresentam de forma instável e frágil. Segundo Silva I. (2006), na concorrência de repertórios culturais e nas relações sociais, há o desenvolvimento de formas de nomeação e identificação visando aclassificação/inferiorização de determinados grupos. As denominações de "caboclo" e "maranhense" são categorias empregadas nas fronteiras ambíguas entre conteúdos pejorativos e representações irônicas das relações desiguais entre grupos regionais de migrantes.

Se por um lado ocorre algo positivo nesse encontro das identidades plurais, que seria "a vivência concomitante de múltiplas culturas", por outro, nessas relações culturais se denotam fragilidades e instabilidades vindas de uma parte dos grupos política e financeiramente mais poderosa - que apresenta sinais de desmerecimento e desqualificação do outro cultural (maranhense), negando-lhe a alteridade. Pensando com Fleuri (2006), o tratamento discriminatório nega o direito de paridade aos "caboclos", aos descendentes de índios ou mesmo aos indígenas não reconhecidos, "maranhenses", e anula o potencial criativo e vital da conexão entre esses diferentes grupos culturais. Em Redenção se observa a presença de outras identidades como

\footnotetext{
Sobre os Mebêngôkre-Kayapó, consultar: https://pib.socioambiental.org/pt/Povo:Mebêngôkre_(Kayapó). A publicação "Povos Indígenas no Brasil" elaborada pelo Instituto Socioambiental traz informações sobre quase todos os grupos indígenas que estão no território brasileiro trazendo informações sobre histórico, localização, práticas culturais e outros aspectos da vida desses povos.
} 
"paranaenses", "gaúchos", "mineiros”, etc. e a desigualdade social que está presente na sociedade brasileira também no espaço escolar, o que pode ser um relevante objeto de estudo para a Geografia escolar.

\section{ENLACES ENTRE GEOGRAFIA ESCOLAR E DIFERENÇA}

Ao pensar o espaço e a educação, Rosendahl (2010) argumenta que a Geografia cultural renovada ${ }^{5}$ deve ser mais que estudo e análise. Sua nítida natureza política deve interagir ativamente nas políticas culturais no exercício do importante papel de reconhecer as diferenças culturais, em busca do estabelecimento da justiça social, evidenciando a relevância que a Geografia tem no processo do reconhecimento e da valorização das identidades e diferenças no espaço escolar.

Diferença, conforme Silva I. (2000), é um conceito que passou a ganhar importância na teorização educacional crítica a partir da emergência da chamada "política de identidade" e dos movimentos multiculturalistas. Nesse contexto, refere-se às diferenças culturais entre os diversos grupos sociais, definidos em termos de divisões sociais tais como: classe, raça, etnia, gênero, sexualidade, religião, regionalidade e nacionalidade. Em algumas das perspectivas multiculturalistas, a diferença cultural é simplesmente tomada como um dado da vida social que deve ser respeitado. Esse autor sugere que as estratégias de trabalhos pedagógicos com a diferença e a identidade, no espaço escolar, superem as concepções liberais, terapêuticas e superficiais, alcançando a estratégia que concebe a diferença e a identidade como questão política.

O espaço geográfico escolar é lugar culturalmente plural, no entanto, na presente proposta de pesquisa delimitamos nossas análises somente sobre as diferenças e identidades culturais étnicas e regionais, unidades que serão brevemente esclarecidas a respeito das suas origens, especificidades e relações com a Geografia escolar.

Nesse sentido, no apoiamos em O'dwyer (2007, p. 4), quando procura "saber o que é especificamente étnico na oposição entre 'eles' e 'nós', e nos critérios de pertença que fundam esta oposição." Segundo essa autora a identidade étnica tem sido diferenciada de "outras formas de identidade coletiva pelo fato de ela ser orientada para o passado." Essa referência a uma origem comum presumida parece recuperar, de certo modo, a própria noção de quilombo definida pela historiografia. Vale assinalar, contudo, que o passado a que se referem os membros desses grupos "não é o da ciência histórica, mas aquele em que se representa a memória coletiva" - portanto, uma história que pode ser igualmente lendária e mítica. "O termo etnia (do grego ethnos: povo, nação) surgiu recentemente na língua francesa (1896)”, segundo Amselle (2017, p. 33).

Para Bonnemaison (2012), a noção de etnia sempre é utilizada com precaução e, ao que tudo indica, com reticências pelos geógrafos tropicalistas. Isso acontece, sem dúvida, porque ela aparece em certo contexto ideológico, ligado ao passado colonial, e porque ficou por longo tempo confinada em uma definição muito restrita. Em defesa da adoção do conceito pelos geógrafos, o autor argumenta:

No entanto, o conceito de etnia é indispensável, porque fundamentalmente ligado ao conceito de área cultural. Para o geógrafo tropicalista, a etnia constitui o primeiro choque - com o fato cultural. Realmente a etnia deve ser considerada num sentido ampliado, sem referência a uma origem biológica comum. A existência ou não de ancestrais (reais ou hipotéticos) a um grupo étnico é coisa secundária. Uma etnia existe primeiro pela consciência que tem de si mesma e pela cultura que produz. É em seu seio que se elabora e se perpetua a soma e crenças, rituais e práticas que fundam a cultura e permitem que os grupos se reproduzam. (BONNEMAISON, 2012, p. 284).

Trazendo o termo etnia para o contexto cultural e histórico, Gomes (2004, p. 50), o esclarece e relaciona com outra categoria da diferença que é a raça. Para a autora:

\footnotetext{
Perspectiva que resultou da geografia cultural que, a partir da década de 70, passou a dialogar com os Estudos Culturais de Raymond Willians, Richard Hoggart e Stwart Hall. Rosendahl (2010), ao escrever sobre geografia cultural e educação, busca referência nesses autores.
} 
[...] o uso do termo etnia ganhou força para se referir aos ditos povos diferentes: judeus, índios, negros, entre outros. A intenção era enfatizar que os grupos humanos não eram marcados por características biológicas herdadas dos seus pais, mães e ancestrais, mas sim, por processos históricos e culturais. Dessa forma, etnia é o outro termo ou conceito usado para se referir ao pertencimento ancestral e étnico/racial dos negros e outros grupos em nossa sociedade.

No Brasil contemporâneo, quando usamos os termos grupos étnicos ou etnia, estamos nos referindo a indígenas, quilombolas e aos povos rom, cólon e sinti, denominados de ciganos. Outros grupos culturais podem ser considerados étnicos, como os judeus que constituem uma religião e podem, inclusive, sofrer racismo. É por isso que dizemos que as diferenças, mais do que dados da natureza, são construções sociais, culturais e políticas.

Uma das questões centrais no debate acerca das questões raciais, diz Ratts (2010), ao defender as Ações Afirmativas, é a utilização da variável raça em políticas públicas, o que para seus opositores indicaria uma ação racista ou uma espécie de "racismo às avessas". Afastando essa compreensão distorcida, o autor explica o termo:

A raça aqui considerada não é uma categoria biológica, advinda do mundo natural. É, sobretudo, uma construção social da diferença baseada em marcadores de corporeidade, em traços fenotípicos como a cor da pele, a textura do cabelo, o formato de nariz e lábios, elementos que não constituiriam um grupo social, mas contribuem, por exemplo, para a identificação racial de quem é negro ou branco no Brasil. A diferença racial, assinalada desta maneira, compõe e agrega ônus ou bônus à trajetória sócio-espacial dos indivíduos racializados. (RATTS, 2010, p. 132-133).

Inserindo o termo na perspectiva de desconstrução do racismo, os apontamentos de Gomes (2004) nos ajudam a entender melhor essa categoria. A autora ressalta que os militantes e intelectuais que adotam o termo raça não o adotam no sentido biológico, pelo contrário, todos sabem e concordam com os atuais estudos da genética de que não existem raças humanas. Na realidade, eles trabalham o termo raça atribuindo-lhe um significado político, construído a partir da análise do tipo de racismo que existe no espaço social brasileiro e considerando as dimensões históricas e culturais a que o termo nos remete.

Quanto à questão da identidade e da diferença regional, Haesbaert (1997) nos propicia a pensar como a diferença cultural ao nível da região se alinhava no tecido social. Segundo o autor, a territorialidade na perspectiva da manifestação da diferença, da identidade do efetivamente outro, entre grupos minoritários, gera processos defensivos que transformam, muitas vezes, esses sujeitos em vítimas marginais do sistema.

Atualmente, é consenso entre os estudos da cultura que as identidades sociais "são produzidas como representação da realidade, visando a um reconhecimento social da diferença" (HAESBAERT, 1997, p. 46). Nesse sentido, permanecem as relevâncias espaciais para definição ou fortalecimento das identidades, inclusive regionais. Quando grupos - de migrantes, por exemplo - encaram o espaço como sentido amplo, significa concebê-lo "num processo e apropriação social não apenas enquanto objeto material, instrumento concreto de controle e ação, mas também como símbolo que tem sua própria eficácia, ou seja, um 'poder simbólico'6, que, em parte, acaba forjando as identidades territoriais." Processo que acontece com os grupos migrantes em processo de reterritorialização ou culturas nativas há muito territorializadas no lugar, a exemplo do que ocorre na região Sul do Pará.

Silva I. (2010), em sua pesquisa acerca da "alteridade maranhense no sudeste do Pará", evidencia a construção da identidade migrante de grupos em condições

\footnotetext{
Poder invisível que só pode ser exercido com a cumplicidade daqueles que não querem saber que lhe estão sujeitos ou mesmo que o exercem. Os sistemas simbólicos devem as suas forças ao fato de as relações de força que neles se exprimem só se manifestarem nele em forma irreconhecível de relações de sentido (deslocamento). O poder simbólico é um poder quase mágico que permite obter o equivalente daquilo que é obtido pela força (física ou econômica), graças ao efeito específico de mobilização, e que só se exerce ser for reconhecido, quer dizer, ignorado como arbitrário (BOURDIEU, 1989, p. 7-14).
} 
subalternas, como aqueles vindos do estado do Maranhão, em alteridade com outros grupos de origem centrosulistas do Brasil.

\begin{abstract}
Desde a década de 1970 sobressaem-se, de uma parte, enunciações que remetem a um ideal de identidade representado pelo Centro-Sul do país e, de outra, (re) criam um Outro representado pela Amazônia nortista - da qual espera-se manter separado. Além disso, no âmbito da construção da fronteira interior têm-se discursos que identificam os Outros que a suposta identidade regional não quer ser/assumir. A questão é como excluir os indesejáveis, isto é, como invisibilizá-los e eliminá-los da identidade regional. Por isso, a existência de discursos que estabelecem classificações na tentativa da construção de territorialidades culturais que valorizam certos grupos e suas contribuições e desqualificam ou invisibilizam outros. Enfim, que produzem "campos de força, referência e aplicabilidade" que atuam também para disciplinar os sujeitos para essas fronteiras - imaginadas e permeadas por nuances políticas e de classe social. (SILVA, I., 2010, p. 53).
\end{abstract}

Percebe-se aqui que a ideia de cultura, que pode ser traduzida em termos de espaço, não pode ser separada da ideia de território. Pois nas palavras de Bonnemaison (2012, p. 288) "é pela existência de uma cultura que se cria um território e é por ele que se fortalece e se exprime a relação simbólica existente entre a cultura e o espaço." A soma de alguns valores referenciados à cultura centrosulista, no caso citado acima, se expressa e se apoia sobre discursos de superioridade e exclusão do outro. Há assim, no contexto da Amazônia Oriental, em específico no Sul e Sudeste do estado do Pará, uma conjuntura histórica, econômica e cultural colocada em questão, onde a cultura hegemônica da frente agropecuária migrante do centro-sul aparece se confrontando com a realidade histórica local. Ao se reproduzirem culturalmente os grupos expressam seu poder.

No campo da Geografia não é comum o interesse pelo outro no espaço da educação e pelas relações de poder implícitas nas construções das diferenças. O outro não no sentido da alteridade radical do outro oposto, mas o outro em termos de interioridade, compreensível e previsível. O outro pensado não com identidades congeladas e essencializadas, mas múltiplas no "sentido de processos, ativas, em fluxos" (SILVA, T., 2014, p. 100).

Nessa perspectiva, a diferença e a identidade que fluem no espaço da escola não devem ser percebidas como algo fixo, mas como construções culturais em movimento. Construções que deve ser explicado "como são produzidas", antes de simplesmente serem respeitadas e admitidas. Pois ainda, conforme Silva T. (2014, p. 100), "a diversidade cultural não é, nunca, um ponto de origem: ela é, em vez disso, o ponto final de um processo conduzido por operações de diferenciação."

Para Brah (2006), o conceito de diferença se refere à variedade de maneiras como os discursos específicos da diferença são construídos, contestados, reproduzidos e ressignificados, a partir das identidades. Trabalhamos com essa noção de "diferença como identidade", que está relacionada "a questões de experiência, subjetividade e relações sociais, pois identidades são inscritas através de experiências culturalmente construídas em relações sociais" (BRAH, 2006, p. 359).

Ao situarmos a questão da identidade no espaço geográfico escolar, podemos dizer que a teia de relações e discursos que ali se estabelecem são expressões identitárias influenciadas e influenciadoras na construção de novas identidades. Pensando com Carvalho (2012, p. 210), "se considerarmos que as identidades são modos de inscrição que vinculam as instituições e os seres ao meio e à cultura, a escola, querendo ou não, estará sempre presente no processo identitário dos adolescentes [...]." No espaço escolar, a forma como os sujeitos são interpelados ou significados faz com que ocorra o jogo das identidades e das identificações, com ganho ou perda, segundo Hall (2014).

Quanto ao espaço geográfico escolar consideramos o que Castrogiovanni e Pinto (2009) apresentam como compreensão do espaço escolar: um subespaço que faz 
parte do todo - uma possibilidade de leitura do espaço geográfico. Para os autores, a partir de uma metalinguagem da Geografia, parece ser possível entendermos a escola como um recorte espacial, aqui traduzido como um subespaço geográfico escolar. Os mesmos esclarecem que não estão utilizando o termo (sub)espaço condicionado a uma submissão do espaço, pelo contrário, refere-se a um determinado recorte, ou ainda, a uma limitação escalar.

Por tudo que já foi dito, em nossa compreensão, esse tipo de espaço é múltiplo e interrelacional, em construção por meio de ações e discursos.

\section{A ABORDAGEM DISCURSIVA DA DIFERENÇA}

Ao eleger os discursos docentes como corpus da pesquisa, nosso propósito é metodologicamente realizar uma análise dos mesmos. Ciente dos afastamentos e aproximações, as noções de discurso acolhidas aqui serão, principalmente, as encontradas em Foucault e Pêcheux. Isso porque:

\footnotetext{
Existem muitos pontos de contato entre aquilo que Michel Foucault elaborou no que se refere ao discurso e aquilo que fez Michel Pêcheux, pelo menos no nível teórico (por exemplo, encontra-se em Foucault uma noção de "formação discursiva" que tem alguns pontos em comum com aquela de Pêcheux), e em particular no nível prático (Foucault nunca tentou elaborar um dispositivo operacional de análise do discurso) [...] Pêcheux partilhava com Foucault um interesse comum pela história das ciências e das ideias que pode explicar por que ambos, mais do que qualquer outro autor, focalizaram o discurso. (HENRY, 1993, p. 38 apud BARONAS, 2011, p. 4).
}

A opção pelas concepções de discursos desses autores se justifica em função dos mesmos tratarem a questão discursiva para além de simplesmente atos de linguagem. Neles, o discurso é tido como elemento constitutivo de realidades, uma noção de discurso que ativamente constrói a sociedade em várias dimensões. Para esses autores - guardadas as diferenças - o discurso é constituído pelos objetos de conhecimento, os sujeitos e as formas sociais do 'eu', as relações sociais e as estruturas conceituais. Em uma perspectiva relacional do espaço, conforme Haesbaert (2014, p. 115), inspirado em Milton Santos, o discurso "envolve, tanto o universo dos objetos quanto dos sujeitos e suas ações, tanto a dimensão dos elementos (aparentemente) fixos quanto móveis, tanto a dimensão material quanto a dimensão imaterial." Acreditamos que nessa dinâmica os discursos têm um papel relevante.

Segundo Foucault (2008), o discurso éo espaço em que saber e poder se articulam, pois quem fala, fala de algum lugar a partir de um direito reconhecido institucionalmente. Esse discurso que passa por verdadeiro e veicula saber (o saber institucional) é gerador de poder. De acordo com Pêcheux (1997), o discurso é o espaço em que emergem as significações. E aqui, o lugar específico da constituição dos sentidos e da formação discursiva, noção que, juntamente com a de condição de produção e formação ideológica, vai formar uma tríade básica nas formulações teóricas da análise do discurso, como aporte teórico metodológico.

\section{DISCURSOS, RELAÇÕES DE PODER E DIFERENÇASNO ESPAÇO ESCOLAR}

O gênero escolhido para ser analisado neste texto é o discurso docente acerca das diferenças no espaço escolar. A coleta desses dados se deu no interior das escolas onde as/os docentes interlocutoras/es trabalham. O discurso aqui trabalhado é a noção tomada como objeto de análise do discurso. Objeto distinto do esquema elementar de comunicação, pois:

[...] desse modo, diremos que [o discurso] não se trata da transmissão de informação apenas, pois, no funcionamento da linguagem, que põe em relação sujeitos e sentidos afetados pela língua e pela História, temos um complexo processo de constituição 
desses sujeitos e produção de sentidos e não meramente transmissão de informação. (ORLANDI, 2015, p. 19).

A autora identifica discurso como processo de identificação de sujeito, de argumentação, de subjetivação, de construção de realidade, etc. O discurso é visto assim como efeito de sentidos entre locutores, sendo que cada sentido se relaciona com muitos outros sentidos. São nas relações que os processos discursivos ganham sentidos.

A partir daqui contextualizaremos os enunciados que possuem muitas possibilidades de interpretações e que foram expressos nas entrevistas realizadas com onze professoras e professores licenciados em Geografia. As perguntas que suscitaram as respostas foram as seguintes: Você como professora/professor percebe se no espaço desta escola existe pluralidade cultural? Você identifica diferenças étnicas e regionais no espaço escolar e em sua sala de aula? Qual sua opinião sobre elas?

Os recortes mais significativos das respostas estão no quadro a seguir. No entanto, os mesmos ainda não serão tratados estritamente como discurso, mas sim como textos. Com isso, eles não deixam de ser unidades de análise, pois carregam materialidade, história, sentidos que receberão tratamento analítico na sequência da escrita. As falas das/os docentes que constituem o corpus para a análise serão identificadas com as iniciais PE (Professor Entrevistado), seguidas da numeração de 1 a 11.

Segundo Guilhaumou (2002), a constituição do corpus não tem por objetivo a seleção dos discursos que serão interessantes de serem analisados por si mesmos, sendo tomados como representativos, considerando que para responder a essa representatividade deverão ser homogêneos no espaço e no tempo e responderem a uma dada ideologia. Nesse sentido, dispusemos esse corpus no quadro a seguir.

Quadro 1 - Discursos acerca de identidade e diferença no espaço escolar.

Discursos Docente

Diferença e relações de poder no espaço escolar

\section{Categorias}

PE1 - [...] a escola tem que considerar [os alunos com alguma marca de diferença], tem que aceitar [a diferença] do jeito que [...] mas dentro do regime né.

PE2 - Assim, ...existe [agressões][...] mas eu não acredito que ela [agressão] seja com a intenção de [...] (faz expressão facial deproblema e reprovação) né?

PE3 - eles [os alunos] não reagem por está na escola, com medo de alguma punição.

PE4 - teve um caso específico de um rapaz [negro] [...] daquela segunda sala, ele assim,cobraram que ele deveria está de uniforme e ele começou cobrar outras coisas, que a escola não favorecia isso [...] Ele disse eu não venho mais, eu vou deixar de estudar porque essa escola cobra isso, cobra aquilo, que eu tenho que vir [...] e quando é pra ela favorecer o meu direito, não estou sendo contemplado...

PE5 - por ser um pouco diferente, até, até no meu caso, por eu falar um pouco diferente, a princípio, eu tive essa dificuldade, não só dentro da sala de aula com os meus alunos, mas eu acabei percebendo que meus próprios colegas né, os professores acabava assim no começo achando estranho::.., não era algo [...] tão agressivo como é dentro de uma sala de aula quanto os alunos, mas não deixa de ser [...] a gente se sente diferente [...] era puxar um pouquinho o "r" e eles já começavam as críticas[...] 0 engraçado que aqui a mistura é muito grande, não deveria ser assim, né . [Procedência regional do docente: Centro-Sul].

PE6 - Então assim, eu evito o máximo de dar liberdade pra eles [alunos] se expandirem, porque se der liberdade ai não dou conta. [...] A maior dificuldade que nós temos aqui é na falta de respeito de aluno com o professor. [fala entendida como no geral]

PE7 - Agora, uma outra questão também, a gente observa muito, até mesmo nos comentários dos professores, né. É a questão da raça, em tese o negrodentro da escola, é mais aguçado pra briga, pra discussão. É porque ele se sente também umpouco discriminado pelos os colegas que colocam eles sempre como os bandidos da situação. Aconteceu uma coisa, foi esse neguim quem fez! Eles colocam. Então eles já têm essa ideia de que eles são é, é [...] discriminados e ai partem pra ignorância também. Uma reação, uma reação ao sistema.

PE8 - mas é aquele negócio né, não tem convívio [referente aos indígenas] né? São muito isolados [quem? Os/as Kaiapó?] assim, principalmente as mulheres. Os homens ainda jogam futebol[...]

PE10 - [...] o pessoal do sul eles tentam de toda forma se sobrepor em relação aos outros. Quem é do Sul [...] e até quem não é, repete algumas falas do sul./

PE11 - Nós tínhamos, nós temos um aluno [indígena] matriculado/ ele muito deslocado! Lógico, ele está numa sala de alunos não indígenas, e, com todos os costumes, com todo o horário, com tudo né. 
Após darmos o tratamento em primeira instância nos dados empíricos, definindo melhor o corpus discursivo e as propriedades discursivas, prosseguiremos agora com a interpretação dos recortes sobre diferenças e relações de poder no espaço escolar. A noção de recorte é introduzida por Orlandi, Guimarães e Tarallo (1989, p. 36), como "unidade discursiva [...] fragmentos correlacionados de linguagem [...] um fragmento da situação discursiva," definido por associações semânticas.

A questão do poder aparece implicitamente nos enunciados docentes quando expressam opiniões acerca de identidades e diferenças. Unidades de sentidos como "regime", "medo" e "punição", historicamente estão associadas às questões de normas, regimento, restrição e proibição. Tais enunciados trazem subentendimentos a respeito de como o poder constitui e é constituído o/no espaço escolar. Conforme Orlandi (2015, p. 81), o subentendido não pode ser asseverado como necessariamente ligado ao dito, mas "ao longo do dizer, há toda uma margem de não ditos que também significam."

A presença do poder no espaço escolar tem a ver com o caráter disciplinar que essa instituição possui desde sua fundação histórica. As relações em seu espaço se dão sob ordens, regras, regulamentos. Nas palavras de Foucault (1979, p. 61) "a disciplina é, antes de tudo, a análise do espaço. E a individualização pelo espaço, a inserção dos corpos em um espaço individualizado, classificatório, combinatório." Ainda conforme esse autor, a disciplina é uma técnica de exercício de poder que não foi inteiramente inventada, mas elaborada em seus princípios fundamentais durante o século XVIII.

Essa afirmação nos possibilita significar que enunciados como o de PE3: eles não reagem por está na escola, com medo de alguma punição, é um discurso que tem origem nas relações hierarquizadas do espaço escolar, onde o sujeito mesmo sendo agredido em suas diferenças, diante do poder das sanções que funcionam como dispositivos de controle, não consegue reagir aos insultos.

No espaço da escola o poder disciplinar molda os comportamentos de acordo com seu regimento [...] a escola tem que considerar, tem que aceitar do jeito que [...] mas dentro do regime né. Nesse enunciado a conjunção coordenativamas, ligando a oração à frase seguinte, introduz uma oposição ou restrição ao que foi dito, [...] a escola tem que aceitar..., mas..., esse termo de ligação condiciona a aceitação dos sujeitos diferentes (indígenas, jovens negros com estilo de cabelo blackpower ou rastafári, surdos, homossexuais) presentes na escola à subordinação ao regime, ao regimento, ao regulamento, às regras, normas e disciplina [...].

Ainda dentro do tópico discursivo ${ }^{7}$ sobre as relações de poder no espaço escolar, identificamos outras marcas onde dispositivos de poder estão imbricados nos enunciados docentes acerca da construção das identidades e diferenças no espaço escolar. Um recorte de fragmentos do discurso de PE4 diz: [...] cobraram que ele deveria está de uniforme e ele começou cobrar outras coisas, que a escola não favorecia isso [...]. O espaço escolar como uma maneira de vivência deveria abrigar o zelo por valores como compromisso mútuo no cumprimento das suas normas, proporcionando direitos na mesma medida em que são exigidos os deveres, ensinando assim o princípio da equidade. Homogeneizada pelo uniforme, a reivindicação da diferença, pelo estudante, se expressa no retorno da cobrança daquilo que a escola, como espaço normalizador, teria o papel de proporcionar a todos. Prática institucional como essa acaba reforçando a imagem do espaço escolar como lugar de relações hierarquizadas.

Os verbos conjugados em terceira pessoa do plural, como em cobraram, indicam a pluralidade de vozes que falam em nome do poder na escola. Ao mesmo tempo esses são sujeitos indeterminados, e não permitem que os identifiquemos precisamente. Embora os sujeitos existam, não é possível determinar quem são, nem pelo contexto, nem pela terminação do verbo. Nesse caso, estamos diante do tipo de silêncio que atravessa a palavra, que "fala" por ela, e que a cala, conforme assegura Orlandi (2015, p. 82) ao comentar a política do silenciamento que perpassa os discursos. Nela uma palavra

Tomado no sentido geral de assunto, o tópico pode ser entendido como "aquilo acerca do que se está falando" (BROWN; YULE, 1983, p. 73 apud FÁVERO, 1999, p. 38) 
apaga outras palavras, para dizer é preciso não-dizer. Sendo assim, não podemos esquecer que "as relações de poder em uma sociedade como a nossa produzem sempre censura, de tal modo que há sempre silêncio acompanhando as palavras."

Como espaço sociocultural a escola é um lugar de disputas e isso influi na maneira de perceber e representar dos seus sujeitos. Segundo Dayrell (1996, p. 2):

\begin{abstract}
A instituição escolar seria resultado de um confronto de interesses: de um lado, uma organização oficial do sistema escolar, que define conteúdos da tarefa central, atribui funções, organiza, separa e hierarquiza o espaço, a fim de diferenciar trabalhos, definindo idealmente, assim, as relações sociais. De outro, os sujeitos - alunos, professores, funcionários, que criam uma trama própria de inter-relações, fazendo da escola um processo permanente de construção social.
\end{abstract}

Ao longo do tempo a escola passou de lugar de desfrute nobre e digno do ócio para os filhos dos grupos abastados financeiramente - para um lugar desprazeroso e angustiante para crianças e jovens em geral. Isso se deu em grande parte pelo conjunto de obrigações e hierarquias imposto aos sujeitos que a ela frequentam, em particular os alunos. Os enunciados de PE4, a seguir, expressam como um estudante significa esse espaço rígido e suas atitudes para livrarem-se dele: Ele disse eu não venho mais, eu vou deixar de estudar porque essa escola cobra isso, cobra aquilo, que eu tenho que vir [...] e quando é pra ela favorecer o meu direito, não estou sendo contemplado [...] (referindo-se ao aluno negro estudante da EJA), demonstração de que no espaço escolar há resistência e luta contra o poder estabelecido, confirmando o que diz Foucault (1979) de que "onde há poder há resistência" e a constatação de que na escola "os sujeitos não são apenas agentes passivos diante da estrutura."

Como sujeitos discursivos os docentes falam do seu lugar de poder como detentores da autoridade do conhecimento e da disciplina nas relações em sala de aula do espaço escolar. A marca dessa posição de poder se evidencia nesse fragmento enunciado por PE6: Então assim, eu evito o máximo de dar liberdade pra eles se expandirem, porque se der liberdade ai não dou conta. [...] A maior dificuldade que nós temos aqui é na falta de respeito de aluno com o professor. O pronome eu seguido do verbo evitar significam, no contexto da sala de aula, que o professor - somente ele, na pessoa dele - está investido do poder para autorizar ou não qualquer possibilidade de autonomia para o aluno diferente, aquele que manifesta comportamento desviante da maioria. O não dito em dar liberdade pode ser negarliberdade, manter o corpo e a vontade relativamente aprisionados enquanto estiver sobre a tutela do docente em sala de aula, representação que demonstra sua filiação à formação discursiva em que "a disciplina fabrica assim corpos submissos e exercitados, corpos 'dóceis'. A disciplina aumenta as forças do corpo (em termos econômicos de utilidade) e diminui essas mesmas forças (em termos políticos de obediência)" (FOUCAULT, 1987, p. 164).

Não se trata de culpabilizar o(a) professor(a) por essa atitude de detentor absoluto dos dispositivos da liberdade dos alunos, mas sim de mostrar que na condição que a instituição escola e a sociedade lhe colocam, como formador das crianças e jovens que lhes são confiados nas escolas, um dos papeis mais constrangedores exigidos a ela/e é esse, o da reprodução do autoritarismo estruturante da sociedade na qual o mesmo está inserido como sujeito. Parafraseando Anjos (2006), ocorre um jogo de compartilhamento de vozes entre o discurso oficial, os movimentos educacionais e a sociedade em geral nessa cobrança sobre o corpo docente.

Cavalcanti (2012), pensando sobre a formação dos jovens alunos na atual sociedade e o que a Geografia pode contribuir com ela, ressalta que essa formação tem um papel relevante no destino da sociedade, por isso é importante que o/a professor(a) considere que seus alunos serão a população adulta do país e do mundo nos próximos anos, na sua complexidade e nas suas diferenças. Essa preocupação é sentida no enunciado a seguir que diz: A maior dificuldade que nós temos aqui é na falta de respeito de aluno com o professor. A falta de respeito aí, não se refere à violência física ou simbólica 
contra as/os docentes, mas à falta de atenção e de interesse por parte dos alunos em relação ao que é ensinado em suas aulas. Na condição de autoridade do conhecimento, as/os docentes não admitem terem seu "professar" ignorado, por isso esse interlocutor considera-se desrespeitado.

Deduz-se também no enunciado falta de respeito, que os(as) docentes não compreendem bem com que tipo de estudantes estão lidando na atualidade e nem sua diversidade. Conhecem pouco sobre as características dos jovens do mundo contemporâneo.

\footnotetext{
[...] essa lógica esquece - que os alunos chegam à escola marcados pela diversidade, reflexo dos desenvolvimentos cognitivo, afetivo e social, evidentemente desiguais, em virtude da quantidade e qualidade de suas experiências e relações sociais, prévias e paralelas à escola. $\mathrm{O}$ tratamento uniforme dado pela escola só vem consagrar a desigualdade e as injustiças das origens sociais dos alunos. Outra forma de compreender esses jovens que chegam à escola é apreendê-los como sujeitos sócioculturais [...]. Trata-se de compreendê-lo na sua diferença, enquanto indivíduo que possui uma historicidade, com visões de mundo, escalas de valores, sentimentos, emoções, desejos, projetos, com lógicas de comportamentos e hábitos que lhe são próprios. (DAYRELL, 1996, p. 5).
}

Os(as) docentes, em parte alheios(as), pois sem uma interpretação aprofundada dessa condição do jovem aluno contemporâneo e com sua formação profundamente marcada pelo paradigma da "sociedade disciplinar", sentem-se sem o controle da situação de ensino na sala de aula, ou seja, diante de alunos desrespeitosos não conseguem, usando a palavras de Foucault (1987, p. 165) vigiá-los, "controlar suas condutas, seus comportamentos, suas atitudes. Não sabem mais como intensificar suas performances, multiplicar suas capacidades, nem como colocá-los no lugar onde eles serão mais úteis."

Observando do ponto de vista da relação de poder entre professor(a) - aluno(a), o discurso [...] porque se der liberdade ai não dou conta [...] é um enunciadodemonstrativo de que a diferença é um desafio no espaço escolar e para seus docentes. Dito no contexto da entrevista em que se perguntava sobre pluralidade cultural e diferenças no espaço escolar, compreende-se nessa unidade discursiva que o não dar liberdade ao aluno diferente significa silenciá-lo, conduta que na opinião de Andrade e Câmara (2015, p. 13) está inscrita na formação discursiva de que "durante muito tempo a diferença foi calada devido a um discurso que, equivocadamente, tomou a igualdade como uniformidade."

O espaço escolar é um encontro de singularidades. Diferença, alteridade e poder se materializam em enunciados discursivos dos diversos sujeitos que se relacionam ali. No fragmento de discurso a seguir identificamos esses diferentes sentidos. Considerando o olhar do outro para si no espaço escolar PE5 diz:

Por ser um pouco diferente [se refere ao sotaque], até, até no meu caso, por eu falar um pouco diferente, a princípio, eu tive essa dificuldade, não só dentro da sala de aula com os meus alunos, mas eu acabei percebendo que meus próprios colegas né, os professores acabava assim no começo achando estranho:..., não era algo[...] tão agressivo como é dentro de uma sala de aula quanto os alunos, mas não deixa de ser [...] a gente se sente diferente [...] era puxar um pouquinho o " $r$ " e eles já começavam as críticas[...] o engraçado que aqui a mistura é muito grande, não deveria ser assim, né. (PE5).

Que marcas ele como outro abriga e que o fazem diferente no espaço escolar? Diferente de quem? Há por certo um grupo de identidade hegemônica na escola? Considerando tais perguntas e o discurso citado, temos PE5 capturado pelo olhar do outro que detém seu ser, pois confessa que teve dificuldade para lidar com o estranhamento de alunos(as) e colegas de trabalho, mas que acabou aceitando a identidade imposta pelo outro: [...] a gente se sente diferente [...] era puxar um pouquinho o " $r$ " e eles 
já começavam as críticas [...]. Situação por Sartre (1999, p. 453) assim descrita: "aprisionado em uma ausência; o outro leva vantagem sobre mim [...] Sou experiência do outro: eis o fato originário", formação discursiva que tem estreita relação com a alteridade nos forçados encontros culturais coloniais denunciados por autores como Frantz Fanon (2008).

Pode-se pensar também que essa experiência de PE5 com o espaço escolar porção das experiências concretas entre os sujeitos escolares - não lhe proporcionou afetos prazerosos, mas sim insegurança, pois passou a conviver com uma "paisagem do medo" composta por enunciados da censura, desaprovação, condenação, reprovação, rejeição, onde prevalece a insegurança no lugar da confiança, cujo efeito dificulta novas territorialidades para ele como outro, significado como diferente.

Numa região de fronteira migratória a vítima esperava encontrar uma alteridade menos constrangedora. Ela enuncia o engraçado é que aqui a mistura é muito grande, não deveria ser assim, né? Nesse caso, a condição de produção desse discurso é o quadro de desconhecimento acerca do sistema de signos no qual os sujeitos migrantes, sejam eles "maranhenses" ou não, estão inseridos, fazendo parte de formações ideológicas e representações ${ }^{8}$ que não falam do outro autêntico, "mas sempre da redução ao mesmo, portanto sem qualquer possibilidade de encontro" de alteridade (GALLO, 2008, p. 2). Ainda conforme esse autor, a educação pode promover encontros alegres e encontros tristes, mas sempre encontros. No caso do encontro de PE5 no espaço escolar, o mesmo foi tomado como tipo de representação - cartesiana - "que redunda que o outro nada mais é do que o mesmo", portanto triste.

$\mathrm{Na}$ escola a diferença está representada pelos sujeitos que fazem parte da comunidade escolar, mas muitas vezes é ignorada ou silenciada. Se a diferença é ignorada, as agressões em decorrência dela se tornam algo de que não se quer falar sobre. Em resposta acerca da ocorrência de agressões em função das diferenças no espaço escolar, obtivemos o seguinte enunciado: Assim, [...] existe [agressões] [...] mas eu não acredito que ela [agressão] seja com a intenção de [...],[faz expressão facial deproblema e reprovação] né? O professor tem o poder de decidir quando é ou não agressão. Segundo Pêcheux (1990), os discursos exprimem uma memória coletiva na qual os sujeitos estão inscritos, o que o autor chama de memória discursiva. $\mathrm{O}$ discurso acima se inscreve na memória discursiva da cordialidade, ou seja, na ideia de que é melhor evitar polêmica, pensamento que tem o papel de acomodar os diferentes de forma subalterna na sociedade, naturalizando as relações de discriminação (violência simbólica) com aqueles que são considerados diferentes no espaço escolar.

Argumentando acerca da ausência de estudos sobre a diversidade étnico-racial brasileira na Geografia, Ratts (2010) constata que os estudos sobre grupos étnicos, até as últimas décadas do século XX, ficaram restritos e trataram, sobretudo, da questão territorial. No entanto, diz o autor, "no que se convencionou denominar de virada cultural ou humanista, os temas concernentes a negros, índios e outros segmentos etnicorraciais, assim como a mulheres e homossexuais, também quase não entraram em cena" (RATTS, 2010, p. 129). Esse hiato em relação à preocupação da ciência geográfica com a questão étnico-racial, envolvendo principalmente negros e indígenas, padece do efeito histórico do período de escravidão em que diferentes formações discursivas e ideológicas se formaram e, uma delas - talvez a ideologia mais evidente e duradoura é a de que a população negra e indígena é inferior e desprovida de humanidade.

Se refletirmos sobre como negros e indígenas eram representados nas narrativas geográficas sobre a constituição e a formação do povo brasileiro, visualizaremos a presença da memória discursiva colonizadora, construída acerca dos grupos étnicos ${ }^{9}$ no Brasil assim:

\footnotetext{
8 Representação aqui está sendo empregada na perspectiva clássica em que "o outro é um produto de meu pensamento, assim como todas as outras coisas das quais posso ter certeza racional. Em outras palavras, no âmbito de uma filosofia da representação, como é a filosofia cartesiana e toda a filosofia hegemônica, desde suas origens até nossos dias, o outro não passa de algo que eu mesmo crio, no pensamento. O outro sou eu mesmo" (GALLO, 2008, p. 2).

9 Estudos antropológicos brasileiros acerca de grupos indígenas e quilombolas adotam a concepção de etnia como um "tipo organizacional"
} 
Nesta geografia imaginativa, considerada não como falsificação, mas como representação, os índios se situam em aldeias muito distantes dos centros urbanos, como se seu ambiente próprio se reduzissem a florestas e matas. São como "orientais" numa terra ocidentalizada. Os negros são igualmente originários de um distante, vasto e misterioso território: a África. No Brasil, parte do Novo Mundo, igualmente exótico, misterioso e distante dos olhos europeus. Neste imaginário o país seria, de modo genérico, mais indígena no Norte e Centro-Oeste, negro ao Nordeste e parte do Sudeste e branco ao Sul. No entanto, no senso comum geográfico praticamente não existiria mais índios nas regiões Nordeste (com exceção do Maranhão), no Sudeste e no Sul. Nas duas últimas regiões mencionadas a existência da população negra e quilombola era posta em questão (LEITE, 1996). Este quadro começa a ser revisto pela permanência por vezes incômoda dos "diferentes" e pelo reconhecimento muitas vezes tardio que alguns atores sociais hegemônicos fazem das identidades de grupos subalternos. (RATTS, 2010, p. 129).

Se quinhentos anos depois a ciência - discurso formador de subjetividades e verdades - ainda percebe/invisibiliza negros e indígenas dessa forma, a opinião da população sobre esses sujeitos, inclusive a escolar, se constitui da mesma forma, com atravessamentos dos interdiscursos que remetem a um sistema de estereótipos como o do interlocutor da pesquisa PE7, na condição de sujeito discursivo, que explica (no recorte a seguir) sobre a presença do negro nas relações espaciais da escola:

Agora, uma outra questão também, a gente observa muito, até mesmo nos comentários dos professores, né. É a questão da raça, em tese o negro dentro da escola, é mais aguçado pra briga, pra discussão. É porque eles se sentem também um pouco discriminados pelos os colegas, que colocam eles sempre como os bandidos da situação. Aconteceu uma coisa, foi esse neguim quem fez! Eles colocam. Então eles já têm essa ideia de que eles são é, é [...] discriminados e aí partem pra ignorância também. Uma reação, uma reação ao sistema. (PE7).

Os interdiscursos oral e visual da superioridade branca de ascendência europeia, presentes nos livros, funcionam como dispositivos invisibilizadores e formadores de subjetividades de auto percepção inferior nos estudantes de outras etnias, inclusive o negro, conforme destacado no fragmento: Então eles já têm essa ideia de que eles são é, é [...] discriminado. O significado desse discurso faz cair por terra o "mito da democracia racial", de que no Brasil não existe racismo e que há uma harmonia nas relações inter étnicas. Discurso ideológico amplamente difundido na sociedade brasileira, que até hoje é utilizado para negar a persistência do racismo e da discriminação racial. Nesse sentido, como pensar em harmonia se ser negro, mesmo após o fim do processo de escravidão, continua sendo, nas palavras de Santos I. (2001, p. 99), "um lugar imposto: o lugar de inferior, de menos inteligente, de menos capaz, de violento, de tribal?"

No trabalho de leitura e interpretação do enunciado de PE7, devemos considerar que essa fala foi produzida no momento histórico brasileiro atual, mas carrega a memória das relações raciais escravistas em que há um falso juízo de valor depreciativo do que é ser negro, construção que, segundo Santos G. (2005) é decorrente de uma afetividade assentada na desconfiança da cosmovisão africana, em razão de nada se assemelhar à visão de mundo cristã ocidental. O texto traz à tona elementos discursivos da nossa história, constitutivos da formação social brasileira "que se estruturou combinando capitalismo e escravidão, o que implicou relações sociorraciais desiguais entre negros, indígenas e brancos" (SANTOS, G., 2005, p. 46).

Para Pêcheux (1997), o sentido de uma palavra, de uma expressão, de uma proposição, etc., não existe em si mesmo (isto é, sua relação não é transparente com a

que considera ter determinados aspectos em comum, a exemplo do território e da cultura, mas dinâmicos: O fato de o pressuposto legal estar referido a um conjunto possível de indivíduos ou atores sociais organizados em conformidade com sua situação atual permite conceituálos, sob uma perspectiva antropológica mais recente, como grupos étnicos, que existem ou persistem ao longo da história como um "tipo organizacional" segundo processos de exclusão e inclusão que permitem definir os limites entre os considerados de dentro e de fora (BARTH, 2000, p. 31). Isso, sem qualquer referência necessária à preservação de diferenças culturais herdadas que possam ser facilmente identificáveis por qualquer observador externo, supostamente produzidas pela manutenção de um pretenso isolamento geográfico e/ou social através do tempo (O'DWYER, 2007, p. 2). 
literalidade do significante), mas, ao contrário, é determinado pelas posições ideológicas que estão em jogo no processo sócio-histórico no qual as palavras, expressões e proposições são produzidas (isto é, reproduzidas).

Colocam eles [os negros]) sempre como os bandidos da situação. Aconteceu uma coisa, foi esse "neguim" quem fez! A memória histórica desse enunciado remonta à Modernidade e seu caráter eurocêntrico em relação à alteridade com o continente africano. Dussel (1993), ao falar das construções teóricas de Hegel para colocar a Europa no centro do mundo, expõe como o filósofo representa a África, um "não lugar histórico." Em sua opinião é a culminação fantástica de uma ideologia racista, cheia de superficialidade, com sentido infinito de superioridade, que mostra bem o estado de espírito da Europa no começo do século XIX e os estereótipos em relação ao negro e ao indígena.

Em relação à diferença inata do aluno indígena, o mesmo encontra na escola diferentes práticas discursivas, negando ou colocando-o como responsável por sua própria exclusão. No caso específico dos espaços escolares por nós pesquisados neste estudo, o discurso que o inferioriza pode ser identificado nas representações discursivas dos textos e mensagens expostos nos murais, no livro didático e na fala de alguns docentes, como os fragmentos a seguir ao falarem da presença e das relações dos(as) alunos(as) indígenas no espaço escolar:

[...] mas é aquele negócio né, não tem convívio né? São muito isolados assim, principalmente as mulheres. Os homens ainda jogam futebol [...]. (PE8).

Nós tínhamos, nós temos um aluno matriculado/ ele muito deslocado! Lógico, ele está numa sala de alunos não indígenas, e, com todos os costumes, com todo o horário, com tudo né. (PE11).

Pensando a questão do que motivou esse enunciado buscamos Foucault (1995), que coloca a seguinte interrogação: o que ocorreu para que houvesse enunciado? Trata-se de buscar na exterioridade de um enunciado determinado, as regras de sua aparição; a relação que mantém com o que enuncia; aquilo a que se refere, o que é posto em jogo por ele. Afinal, como afirma o autor: por que esse enunciado e não outro em seu lugar? Tais questionamentos podem ser dirigidos ao enunciado acima.

Para que esse enunciado viesse a ser dito, alguns dispositivos foram acionados. Um deles é que ouve uma interrogação da nossa parte ao interlocutor, uma provocação à reflexão sobre a presença indígena no espaço da escola e sua condição como aluno(a). Para citar outro motivo, PE8 é um sujeito histórico com experiência de mais de três décadas de docência nas escolas onde estamos realizando a pesquisa, vivência que Ihe possibilita refletir sobre a constituição, as relações e as práticas espaciais na escola. Esse aspecto revela a presença de dada memória discursiva, construída ao longo da história, e aponta-nos elementos da formação discursiva engendrada pelo colonizador acerca das culturas nativas da região.

Quanto às perguntas: por que esse enunciado aparece assim e não de outra forma? Qual é a relação dele com o aluno indígena (referente)? PE11 remete às palavras do Xamã Yanomami Davi Kopenawa, no livro "A queda do Céu"10:

Os brancos nos chamam de ignorantes apenas porque somos gente diferentes deles. $\mathrm{Na}$ verdade, é o pensamento deles que se mostra curto e obscuro. Não consegue se expandir e se elevar, porque eles querem ignorar a morte [...] ficam sempre bebendo cachaça e cerveja, que Ihes esquentam e esfumaçam o peito. É por isso que suas palavras ficam tão ruins e emaranhadas. Não queremos mais ouvi-las. Para nós a política é outra coisa. São as palavras de Omama e Xapiri que ele nos deixou. São

\footnotetext{
10 "A queda do céu" é um trabalho antropológico publicado no Brasil em 2015, simétrico e dialógico de confissões ritmadas e aceleradas que nos desemudece e tanto provoca. É resultado de um pacto etnográfico, entre o etnólogo francês, Bruce Albert - que trabalha há quatro décadas na terra indígena Yanomami - e o xamã e porta-voz Yanomami, Davi Kopenawa - presidente fundador da associação Hutukara representando a maioria dos Yanomami no Brasil - após longos anos de trabalho juntos. A narrativa fala do Brasil do ponto de vista dos povos indígenas em constante embate com os não-índios/Brancos (de dentro e de fora das fronteiras geopolíticas brasileiras) (SANTOS; KOPENAWA; ALBERT, 2017, p. 159).
} 
as palavras que escutamos no tempo dos sonhos e que preferimos, pois são nossas mesmo. Os brancos não sonham tão longe quanto nós. Dormem muito, mas só sonham consigo mesmo. (KOPENAWA; ALBERT, 2015, p. 37).

Compreensão antropológica como essa dificilmente adentra a escola e os currículos de formação de professores de Geografia e demais disciplinas, pois, capturada pelo pensamento cartesiano e etnocêntrico, a escola acaba esquecendose tanto do outro diferente e suas "práticas espaciais" (espaço percebido), "espaços de representação" (espaço vivido), nos termos de Lefebvre (2006), quanto as próprias ideias de "representações do espaço" ou o "espaço concebido" (HAESBAERT, 2010, p. $16)$, na sua cultura. Esse movimento, se permitido, possibilitaria aos sujeitos - em suas pluralidades culturais - perceberem e refletirem ao mesmo tempo na/com as diferenças, talvez por isso haja pouca expansão do pensamento promovido pela escola.

Considerando o discurso: não tem convívio né? São muito isolados assim, principalmente as mulheres... podemos pensar historicamente: o que impede o convívio e provoca o isolamento entre indígenas e não indígenas na cidade e na escola? Seria reflexo da política de extermínio iniciada no processo de colonização europeia e que se estende até nossos dias? A memória não deixou que nunca mais o povo indígena confiasse no não indígena? Ou seria a percepção depreciativa que o homem branco tem do indígena, como enunciou Kopenawa no fragmento acima? Ou pode ser as duas situações juntas e muitas outras conjugadas que compõem um repertório de práticas e representações racistas?

É possível que, além de não se sentir contemplado em sua cultura pelo ensino na escola, todos os conflitos e tensões que marcaram a existência do seu povo, levandoos a quase extinção no passado, sua continuidade com reflexos nos dias atuais e consequências imensuráveis, tenham levado o(a) indígena a evitar ao máximo a interatividade com os(as) não indígenas, já que ela só lhe causou/causa prejuízo até agora. Segundo Calderoni (2011), o aluno indígena busca esconder seu passado como estratégia para "fugir" da discriminação e da inferiorização que marcam as relações com os que os reconhecem na escola. Essa estratégia deve ser entendida como esforço de inserção e negociação com os outros sujeitos do espaço escolar, cientes do lugar de inferioridade em que estão postos, enquanto índios.

Para Almeida (2013), o discurso reflete um momento mais performático ou criativo, portanto, convém aos geógrafos verem as práticas discursivas como modo de investigação. Se um enunciado diz "muito isolado", esse dizer é uma prática geográfica e, como tal, deve ser considerado constituído e constituinte de espaço. Caberia também aqui perguntar: isolado em relação a que? A quem? Isolado, segundo o Dicionário Aurélio online, significa separado, afastado, incomunicável. Se estão na escola, os alunos indígenas encontram-se em um meio social, composto por outros alunos iguais na condição de estudantes e diferentes em suas culturas. Estão também em relação com um conjunto de objetos, como os murais da escola, móveis, livros, aparelhos tecnológicos e instrumentos pedagógicos utilizados pelos professores. Essa relação é atravessada por diferentes discursos, olhares e percepções.

Mesmo assim, em meio ao espaço institucional etnocêntrico, encontra-se enunciados de alteridade como esse, que justifica o isolamento do aluno indígena da seguinte forma: Lógico, ele está numa sala de alunos não indígenas, e, com todos os costumes, com todo o horário, com tudo né. O interlocutor fala de um espaço que é culturalmente muito estranho ao mundo cultural do aluno indígena, onde ele não se vê representado e nem a cultura do seu povo. Um lugar onde o mesmo não se reconhece e, no lugar da troca de saberes, predomina a imposição. As relações culturais hierarquizadas no espaço escolar se apresentam como um espaço excludente para as culturas não hegemônicas.

Quanto às diferenças regionais aqui também analisadas, a ideia de formação da "nação" nos ajuda em parte a compreendê-las. Segundo Foucault (1979), as 
determinações espaciais são estratégias que se camuflam em formas de discursos e estão eminentemente ligadas às relações de poder. O conceito moderno de "nação" - que advém das franjas do romantismo no século XIX e emerge concomitante à consolidação do Estado-nação europeu - é uma boa ilustração dessa postura estratégica. Conforme Hobsbawm (1999), alguns critérios são utilizados para que um povo se denomine como tal. Um desses critérios é dado pela existência de uma elite cultural longamente estabelecida que possui um vernáculo administrativo e literário escrito. Ancorado nesse critério, o sistema de dominação colonial europeu se impôs às demais regiões e povos do mundo Silveira (2007, p. 61) nos ajuda exemplificar os desdobramentos de "nação":

\begin{abstract}
É importante considerar aqui que, para além do vocábulo "nação", todas as suas derivações - nacional, nacionalismo, etc. - também ocultaram (e ainda ocultam) discursos e representações de poder. Quase como uma extensão deste sentido, o mesmo uso se deu com outras determinações espaciais, como é o caso da palavra "região", igualmente acompanhada por suas derivações [...].Tal como ocorre com a "nação", a "região" se liga diretamente às relações de poder e sua espacialização.
\end{abstract}

As formações espaciais regionais brasileiras são expressões do poder de determinadas identidades culturais que, no processo histórico de formação do território brasileiro e de frentes mais recentes de exploração desse, tentam estabelecer hegemonias de suas culturas como estratégias de territorialização. A Região amazônica, como espaço de fronteira migratória, é palco de disputas culturais, já que lá as culturas migrantes - principalmente as de origem centrosulistas - procuram a todo custo tornarem-se hegemônicas. Sobre as relações de poder entre as culturas na cidade de Redenção, locus da pesquisa, vejamos o fragmento enunciativo a seguir:

[...] o pessoal do sul eles tentam de toda forma se sobrepor em relação aos outros. Quem é do Sul [...] e até quem não é, repete algumas falas do Sul. (PE10).

A leitura desse enunciado coloca em evidência as condições de fronteira simbólica na cidade e no espaço escolar. Quadro onde sujeitos migrantes e nativos delimitam-se no plano cultural e social, estabelecendo os espaços que cada um pode ocupar em relação ao grupo e à cultura. O sujeito discursivo, ao identificar o outro "eles" (pronome da terceira pessoa do plural) como do Sul, indica ser ele (sujeito) de outra região. No ato de perceber que "eles", o pessoal do Sul "tenta sobrepor sua cultura" há a denúncia sobre o caráter da relação de dominação e não de alteridade de uma cultura sobre as outras, pois a intenção dos centrosulistas em reduzir o outro no mesmo, elimina a possibilidade do verdadeiro encontro, inviabiliza pensar o não sulista em sua diferença e como diferença.

Silva I. (2010), ao estudar em seu doutoramento as experiências da alteridade como (entre) lugar da produção de processos de subalternização e hierarquização sociocultural no sudeste paraense, identificou a região como fronteira cultural, entendida assim:

[...] como lugar terceiro das interações e contraditoriedade sociocultural no contexto de reterritorialização de migrantes no sudeste do Pará. [...] como essa comunicação tem atuado também para produzir diferenciação e hierarquização sociocultural e construído o maranhense como categoria étnica. As interações socioespaciais e as experiências da alteridade são dramatizadas no combate pela memória da migração e de reterritorialização. Por isso, a luta de representação envolve processos de dominação e exclusão, bem como de inscrição cultural da alteridade como força insurgente, empreendida por grupos em condições de subalternidade, que visa à aquisição de poder e maior participação na história. (SILVA, I., 2010, p. 8-12).

O agente interno - no processo de colonialidade - opera como se descobrisse a Amazônia e, da forma como aconteceu quando do "descobrimento da América", investe sobre o "encobrimento do outro" (DUSSEL, 1993, p. 24). A identidade do outro amazônico é capturada para ao mesmo tempo ser negada. Nota-se, no caso de Redenção, que, 
além da cultura hedonista, dispositivos econômicos de violência física e simbólica são acionados para produzir diferenciação e hierarquização nos diferentes espaços de relação na cidade, inclusive na escola. A unidade discursiva a seguir evidencia o outro sendo transformado em sulista ao adotar o discurso que encobre sua diferença.

Quem é do Sul [...] e até quem não é, repete algumas falas do Sul.

Esse processo de conversão não se dá de forma voluntária, mas sobre relações de poder, subalternização e resistência. Opera, nesse enunciado, a formação discursiva da colonização em que o outro é a "besta", a "matéria bruta", a massa rústica "descoberta" para ser civilizada pelo "ser" sulista de cultura superior, mas "em-coberta" em sua alteridade. Formação discursiva em que o outro, em sua diferença, é negado como outro. Nesse sentido, há investimentos por parte dos sulistas para sujeitá-lo, aliená-lo e incorporá-lo à totalidade dominadora como coisa, instrumento, como oprimido, como encomendado, como assalariado [...] (DUSSEL, 1993, p. 36). Apesar das tentativas de apagamento do outro, nota-se através das resistências que é impossível banir a diferença, uma vez que as contranarrativas irrompem no nível performático.

\section{CONSIDERAÇÕES FINAIS}

Neste artigo, abordamos algumas representações de identidades e diferenças étnicas e regionais presentes no espaço escolar, a partir de enunciados discursivos de professoras e professores de Geografia do Ensino Fundamental, Anos Finais, de escolas públicas. Considerando que os discursos se organizam como prática social em cada espaço onde ocorrem, entendemos que no espaço escolar as representações discursivas acerca do outro expressam e ocultam - paradoxalmente - questões que contribuem para a naturalização, por exemplo, de estereótipos, discriminações e racismo, bem como podem revelar alteridades positivas.

Desse modo, dedicamo-nos a apresentar e analisar fragmentos de falas docentes, procurando identificar marcas de formações ideológicas e de outros discursos que atravessam seus dizeres quando se referem à presença e às relações espaciais entre sujeitos culturais indígenas, negros, migrantes "maranhenses" e a instituição escolar. Nesse percurso foi possível perceber ditos e não ditos acerca das identidades e diferenças, o que evidenciou lacunas na formação a respeito da temática e também receio dos(as) interlocutores(as) em tocar em alguns detalhes da questão, o que demonstra que o assunto ainda é tabu entre eles(as) e provavelmente no espaço escolar. Se há interdição em certos discursos, nega-se em combo as oportunidades de reconhecer e dialogar sobre fatores sociais que geram exclusão, como por exemplo, o racismo e a xenofobia, o que, por consequência, reforça o déficit de cidadania presente na sociedade.

Denota-se nos discursos docentes a identificação das diferenças ao mesmo tempo em que se percebe uma tímida afirmação da diversidade cultural, realidade brasileira que foi apagada no "discurso dos vencedores". Apesar de pouca convicção e de não se sentirem muito à vontade para falar sobre as diferenças étnicas e também regionais, alguns sujeitos colaboradores(as) sinalizaram conhecer parte do desmonte crítico às verdades estabelecidas, que vem sendo efetuado pelos movimentos civis organizados em torno da defesa das diferenças, retraçando um novo mapa da geografia identitária no Brasil, "nação construída sobre representações congeladas de si mesma" (CARONE, 1998, p. 181).

Por fim, o ensino de Geografia para futuros professores e professoras demanda abordagens que percebam, se preocupem e valorizem a pluralidade cultural que institui o espaço escolar. Isso pensando em desconstruir e desnaturalizar as relações hierarquizadas que, segundo Lima e Tonini (2016), resultam em binarismos identitários como: dominado e dominante, imperialista e colonizado, bonito e feio, branco e preto, rico e pobre, gordo e magro; que são naturalizados por meio de estratégias discursivas que levam ao silenciamento, à negação e ao apagamento do outro diferente. 
Tencionar que o espaço escolar torne-se um lugar que haja justiça social por meio de relações respeitosas e oportunidades iguais para os estudantes e demais sujeitos escolares, demanda mergulhos nas espacialidades e categorias discursivas que compõem os discursos docentes acerca das identidades e diferenças na escola, pois, assim, tornar-se-á possível identificar, monitorar, evitar e descontruir - quando ocorrer situações de preconceito e racismo que excluem os sujeitos identificados diferentes ou que reivindicam suas diferenças.

\section{REFERÊNCIAS}

ALMEIDA, Maria Geralda de. A propósito do trato do invisível, do intangível e do discurso na geografia cultural. Revista da ANPEGE, v. 9, n. 11, p. 41-50, jan./jun. 2013.

AMSELLE, J.-L. Etnias e espaços: por uma antropologia topológica. In: AMSELLE, J.-L.; M'BOKOLO, E. (Org.). No centro da etnia: etnias, tribalismo e Estado na África. Tradução Maria Ferreira. Petrópolis-RJ: Vozes, 2017. p. 23-54.

ANDRADE, M.; CÂMARA, L. Diferenças silenciadas e diálogos possíveis: a pesquisa em educação como superação de silenciamentos. In: ANDRADE, M. (Org.). Diferenças silenciadas: pesquisa em educação, preconceitos e discriminações. Rio de Janeiro: 7 Letras, 2015. 179 p.

ANJOS, H. P. dos. Por que a escola não é azul?: os discursos imbricados na questão da inclusão. Jundiaí-SP: Paco Editorial, 2006. 344 p.

BARONAS, R. L. Formação discursiva e discurso em Foucault e em Pêcheux: notas de leitura para discussão. In: SEMINÁRIO DE ESTUDOS EM ANÁLISE DO DISCURSO, 5., 2011, Porto Alegre. Anais... Porto Alegre: UFRGS, 2011. p. 1-7.

BARTH, Fredrik. O guru, o iniciador e outras variações antropológicas. LASK, Tomke (org.). Rio de Janeiro: Contra Capa Livraria, 2000.

BONNEMAISON, J. Viagem em torno do território. In: CORREAA, R. L.; ROSENDAHL, Z. Geografia cultural: uma antologia. Rio de Janeiro: Eduerj, 2012. p. 279-304.

BOURDIEU, P. O poder simbólico. Rio de Janeiro: Bertrand Brasil, 1989. 322 p.

BRAH, A. Diferença, diversidade, diferenciação. Cadernos Pagu, v. 26, p. 329-376, jan./jun. 2006.

BRASIL. Ministério da Educação. Secretaria de Educação Básica. Diretoria de Currículos e Educação Integral. Diretrizes Curriculares Nacionais Gerais da Educação Básica. Brasília: MEC; SEB; DICEI, 2013. 542 p.

CALDERONI, V. A. M. de 0 . Nas tramas da igualdade e da diferença frente à alteridade dos alunos indígenas. 2011. 392 f. Tese (Doutorado em Educação) - Universidade Católica Dom Bosco, Campo Grande-MS, 2011.

CARONE, I. Igualdade versus diferença: um tema do século. In: AQUINO, J. G. (Org.). Diferenças e preconceito na escola: alternativas teóricas e práticas. São Paulo: Summus, 1998. p.171-182.

CARVALHO, M. A construção das identidades no espaço escolar. Revista Reflexão e Ação, Santa Cruz do Sul, v. 20, n. 1, p. 209-227, jan.jjun. 2012.

CASHMORE, E. Dicionário de relações étnicas e raciais. Tradução Dinah Kleve. São Paulo: Summus, 2000. 598 p. CASTROGIOVANNI, A. C.; PINTO, K. O (sub)espaço geográfico escola. Geografia: Ensino \& Pesquisa, Santa Maria, v. 13 n. 2, p. 285-294, 2009.

CAVALCANTI, L. de S. O ensino de geografia na escola. Campinas-SP: Papirus Editora, 2012. 208 p. 
COSTA, B. P. da. A escola como espaço: identidades de gêneros e sexualidades e suas hierarquias. Revista da Associação Nacional de Pós-graduação e Pesquisa em Geografia (Anpege), v.12, n. 19, p. 204-225, jul./dez. 2016.

DAYRELL, J. T. A escola como espaço sócio-cultural. In: (Org.). Múltiplos olhares sobre cultura e educação. Belo Horizonte: Editora UFMG, 1996. p. 136-161.

DUSSEL, E. 1492 o encobrimento do outro: a origem do mito da modernidade. Petrópolis-RJ: Vozes, 1993. 190 p.

FANON, Frantz. Pele negra, máscaras brancas. Trad. Renato da Silveira .Salvador: EDUFBA, 2008. p. 194.

FÁVERO, L. L. O tópico discursivo. In: PRETI, D. (Org.). Análise de textos orais. São Paulo: Humanitas - FFLCH/ USP, 1999. $236 \mathrm{p}$.

FERNANDES, C. A. Análise do discurso: reflexões introdutórias. São Paulo: Editora Claraluz, 2008. 100 p.

FLEURI, R. M. Políticas da diferença: para além dos estereótipos na prática educacional. Educação \& Sociedade, Campinas, v. 27, n. 95, p. 495-520, maio/ago. 2006.

FOUCAULT. M. A arqueologia do saber. Trad. de Luiz Felipe Baeta Neves. Rio de Janeiro: Forense Universitária, 2008. 244p.

M. O sujeito e o poder. In: RABINOW, P.; DREYFUSS, H. (orgs.). Michel Foucault: uma trajetória filosófica. Rio de Janeiro: Forense Universitária, 1995.

M. Vigiar e punir: nascimento da prisão. Tradução Raquel Ramalhete. Petrópolis: Vozes, 1987. 288 p. Graal, 1979.

Michel. Microfísica do poder. Organização e tradução de Roberto Machado. Rio de Janeiro: Edições

GALLO, S. Eu, o outro e tantos outros: educação, alteridade e filosofia da diferença. In: CONGRESSO INTERNACIONAL COTIDIANO, 2., 2008, Niterói-RJ. Anais... Niterói-RJ: UFF, 2008. p. 1-16.

GOMES, N. L. Alguns termos e conceitos presentes no debate sobre relações raciais no Brasil: uma breve discussão. 2004. Disponível em: <www.acaoeducativa.org.br/fdh/?p>. Acesso em: 28 fev. 2017.

GUILHAUMOU, J. Le corpus em analyse de discours: perspective historique. Corpus - Corpus et recherches linguistiques, n. 1, nov. 2002.

HAESBAERT, R. Des-territorialização e identidade: a rede "gaúcha" no nordeste. Niterói-RJ: EDUFF, 1997. 293 p.

O espaço como categoria e sua constelação de conceitos: uma abordagem didática. In: TONINI, I. M. et al. (Org.). 0 ensino de geografia e suas composições curriculares. Porto Alegre: Editora Meditação, 2014. p. 109121. 3, jan.jun. 2010.

Região, regionalização e regionalidade: questões contemporâneas. ANTARES: Letras e Humanidades, n.

HALL, S. Quem precisa da identidade? In: SILVA, T. T. (Org.). Identidade e diferença: a perspectiva dos estudos culturais. Petrópolis-RJ: Vozes, 2014. p. 103-133.

HOBSBAWM, E. J. Nações e nacionalismo: desde 1780. Rio de Janeiro: Paz \& Terra, 1999. 230 p.

KOPENAWA, D.; ALBERT, B. A queda do céu: palavras de um xamã yanomami. São Paulo: Companhia das Letras, 2015. $729 p$.

LEFÉBVRE, H. A produção do espaço. Trad. Doralice Barros Pereira e Sérgio Martins (do original: La production de l'espace. 4e éd. Paris: Éditions Anthropos, 2000). Primeira versão: início, fev. 2006. 
LIMA, Romise Inez de; TONINI, Ivaine Maria. Na sala de aula: a África de meus alunos. CASTROGIOVANNI, A. C. et al. (orgs.). Movimentos para ensinar geografia: oscilações. Porto Alegre: Editora Letra 1, 2016. 312p.

LIMA, M. P. De Boca da Mata à Redenção: uma outra história (1959 a 1999). Goiânia: Kelps, 2013. 116 p.

O'DWYER, E. C. Terras de quilombo: identidade étnica e os caminhos do reconhecimento. TOMO, São CristóvãoSE, n. 11, p. 1-16, jul./dez. 2007.

ORLANDI, E. P. Análise de discurso: princípios e procedimentos. Campinas-SP: Pontes Editores, 2015. 98 p.

ORLANDI, E. P.; GUIMARÃES, E.; TARALLO, F. L. Vozes e contrastes: discurso na cidade e no campo. São Paulo: Cortez, 1989.

PÊCHEUX, M. Discurso: estrutura ou acontecimento. Campinas: Pontes, 1990.

M. Semântica e discurso. Uma crítica à afirmação do óbvio. Tradução Eni Pulcinelli Orlandi [et al.] Campinas: Editora da Unicamp, 1997.

PINEDA-ALFONSO, J. A. Trabajar el problema de la convivência en el espacio escolar: una experiencia de enseñanza de lãs ciências sociales en um entorno marginal de Sevilla. In: CASTROGIONVANNI, A. C. et al. (Org.). Movimentos para ensinar geografia-oscilações. Porto Alegre: Editora Letra1, 2016. 311 p.

RATTS, A. Geografia, relações étnico-raciais e educação: a dimensão espacial das políticas de ações afirmativas no ensino. Revista Terra Livre, São Paulo, ano 26, v. 1, n. 34, p. 125-140, jan./jun. 2010.

ROSENDAHL, Z. Espaço e educação na geografia cultural. Espaço e Cultura, Rio de Janeiro: UERJ, n. 28, p. 106113, jul./dez. 2010.

SANTOS, G. A. dos. Ainvenção do ser negro: um percurso das ideias que naturalizaram a inferioridade dos negros. São Paulo: Educ/Fapesp; Rio de Janeiro: Pallas, 2005. 176 p.

SANTOS, I. A. dos. A responsabilidade da escola na eliminação do preconceito racial: alguns caminhos. In: CAVALLERO, E. (Org.). Racismo e anti-racismo na educação: repensando nossa escola. São Paulo: Selo Negro, 2001. $213 p$.

SANTOS, T. D. L. B.; KOPENAWA, D.; ALBERT, B. A queda do céu: palavras de um xamã Yanomami. Tradução de Beatriz Perrone-Moisés. São Paulo: Companhia das Letras, 2017. 729 p.

SARTRE, J. P. O ser e o nada: ensaio de ontologia fenomenológica. Petrópolis-RJ: Vozes, 1999. 784 p.

SILVA, I. S. da. Fronteira cultural: a alteridade maranhense no sudeste do Pará (1970-2008). 2010. 230 f. Tese (Doutorado em História)- Universidade Federa de Goiás, Goiânia, 2010.

. Migração e cultura no sudeste do Pará: Marabá (1968-1988). 2006. 181 f. Dissertação (Mestrado em História)- Universidade Federal de Goiás, Goiânia, 2006.

SILVA, T. T. da. A produção social da identidade e da diferença. In: (org.). Identidade e diferença: a perspectiva dos estudos culturais. Rio de Janeiro: Vozes; 2014. p. 73-102.

Teoria cultural e educação: um vocabulário crítico. Belo Horizonte: Autêntica, 2000. 128 p.

SILVEIRA, Roberto Azoubel da Mota. A reinvenção do Nordeste nas crônicas d'O Carapuceiro. Tese (Doutorado em Letras) - Pontifícia Universidade Católica do Rio de Janeiro, Rio de Janeiro, 2007.

TONINI, I. M. Identidades capturadas: gênero, etnia e geração na hierarquia territorial dos livros didáticos de Geografia. 2002. 139 f. Tese (Doutorado em Educação)- Universidade Federal do Rio Grande do Sul, Porto Alegre, 2002. 